\title{
Free Trade Agreements in Asia: Economic imperatives or footholds for external relevance?*
}

\author{
María J. García \\ National Centre Research on Europe \\ University of Canterbury
}

\begin{abstract}
Summary: I. Introduction. - II. Free Trade Agreements.-III. European Union Free Trade Agreement Strategy. 1. A Realist EU Trade Policy?-IV. The European Union's Free Trade Agreements in East Asia. 1. EU-Asia Economic Relations Overview. 2. Competition and Choice of FTA Partners. 3. Negotiating FTA with Asian States.-V. Concluding Remarks.
\end{abstract}

\begin{abstract}
This paper charts the motivations behind the European Union's free trade agreements (FTAs) in East Asia. Economists have cast doubts as to the benefits of individual FTAs between large economies and smaller ones, such as the agreements under negotiation between the EU and Vietnam, Singapore, Malaysia and India. This paper engages with this literature by focusing on the interplay between material interests pursued by the EU's trade policy in Asia and the political motivations, amongst which maintaining a significant international engagement and shaping future economic governance occupy a prime role. An empirical analysis based on documentary and interview materials is subject to process tracing to further our understanding of how different interests and ideas are articulated in foreign policy.
\end{abstract}

Keywords: FTAs, EU-Asia Relations, Trade policy, Negotiations.

Resumen: Este artículo explora los motivos tras la política de acuerdos de libre comercio (ALC) de la Unión Europea en el este asiático. Los economistas se muestran escépticos respeto a los beneficios de ALCs entre economías asimétricas como en las negociaciones entre la UE y Vietnam, India, Malasia y Singapur. Teniendo esto en cuenta, este artículo investiga la interrelación entre los intereses materiales de la política comercial de la UE y los objetivos políticos que buscan los acuerdos, como mantener una presencia global y moldear la futura gobernanza económica. El análisis empírico utiliza entrevistas y documentos oficiales para trazar cómo los distintos intereses e ideas normativas influyen en, y se articulan a través de, la política comercial exterior de la UE.

Palabras clave: Acuerdos de Libre Comercio, Relaciones UE-Asia, Política comercial, Negociaciones.

* Recibido 7 de marzo de 2012, aceptado 15 de marzo de 2012. 


\section{Introduction}

This article charts the motivations behind the European Union's recent free trade agreements (FTAs) and FTA negotiations in Asia. Economists have cast doubts as to the benefits of individual FTAs between large economies and smaller ones, in terms of GDP indicators and industrialization, such as the agreements under negotiation between the EU and Vietnam, Singapore, Malaysia and India. The narrative of the EU's trade policy in Asia engages with this literature by focusing on the interplay between material interests pursued by the EU's trade policy in Asia and the political motivations, amongst which a realist foreign economic policy aimed at maintaining a significant international engagement and shaping future economic governance occupies a prime role. The rest of the article is divided into four more sections. Section two explains current trends in FTA and explanations thereof. Section three focuses on the aims and recent trajectory of the European Union's trade policy, in particular its position on FTAs, and outlines the theoretical implications of a realist EU trade policy. Section four analyses the economic relation and ongoing FTA negotiations between the EU and Asian states, and a final section offers some concluding remarks.

\section{Free Trade Agreements}

Free Trade Agreements (FTA), Preferential Trade Agreements (PTA) and Regional Trade Agreements (RTA) ${ }^{1}$ represent tools for the furthering of economic relations between two or more parties (states or regional groupings) by facilitating trade and investment exchanges. The scope and coverage of FTAs varies greatly, but what is clear is that since the global waves of economic reform and liberalization of the late 1980s and 1990s, FTAs have multiplied five-fold, from 86 to 421 , over the past two decades from $1990^{2}$. This new wave of FTAs even involves states traditionally committed to multilateral liberalization, and is characterized by agreements between

${ }^{1}$ Most agreements are officially labeled FTAs, even if they do not liberalise 100 percent of exchanges and would be more aptly named PTAs, however, for simplification purposes and consistency with the official names of the agreements, FTA will be used throughout the article to encompass FTAs, PTAs and RTAs.

2 WORLD TRADE ORGANISATION (WTO), World Tariff Profile. 2011 http://stat. wto.org/TariffProfile/WSDBtariffPFExport.aspx ?Language=E\&Country=I (last accessed 05/12/2011). 
developed and developing states, cross-regional negotiations, and faster negotiations ${ }^{3}$.

Studied largely by economists, concerned with the technical and costly effects of a complex 'spaghetti bowl' ${ }^{4}$ of tariffs, rules of origin and regulations ${ }^{5}$, FTAs have been viewed as both stumbling blocks ${ }^{6}$ and stepping stones to successful global economic liberalization ${ }^{7}$ via the World Trade Organisation (WTO) within a debate on the compatibility of bilateral and multilateral liberalization ${ }^{8}$. This literature shares the assumption that free trade and liberalization lead to growth ${ }^{9}$. To substantiate this, models concerned with discriminatory effects of FTAs as they result in trade diversion away from non-preferential partners (non-FTA partners) and trade creation with FTA partners produced by lowering tariffs and nontariff barriers to FTA partners, suggest outsiders to FTAs will want to become insiders thus expanding free trade. Richard Baldwin's metaphor of the 'domino effect' offers a good example ${ }^{10}$. Similarly, Gene Grossman and Elhaman Helpman claim that trade diversion provides the principal motive for forming new

${ }^{3}$ FIORENTINO, R., VERDEJA, L. and TEQUEBOEUF, C., 'The Changing Landscape of Regional Trade Agreements: 2006 Update', Discussion Paper N. ${ }^{\circ}$ 12, WTO, Lausanne, 2007.

${ }^{4}$ BHAGWATI, J., “The World Trade System”, Journal of International Affairs, Vol. 48, N. ${ }^{\circ}$ 1, 1994, pp. 279-285.

5 BALDWIN, R., "Multilateralising Regionalism: Spaghetti Bowls as Building Blocs on the Path to Global Free Trade", The World Economy, Vol. 29, N. ${ }^{\circ} 11,2006$, pp. 1451-1518.

6 BALDWIN, R., "A Domino Theory of Regionalism", Working paper 857, Centre for Economic Policy Research, London, 1993; BHAGWATI, J., "The World Trade System", Journal of International Affairs, Vol. 48, N. ${ }^{\circ}$ 1, 1994, pp. 279-285; BHAGWATI, J., Termites in the Trading System: How Preferential Agreements Undermine Free Trade. Oxford University Press, Oxford, 2008; THUROW, L., Head to Head: The Coming Battle among Japan, Europe and America, William Morrow, New York, 1992; KRUGMAN, P., "Regionalism versus multilateralism: analytical notes". In: DE MELO, J. and PANAGARIVA, A. (eds.), New Dimensions in Regional Integration, Cambridge University Press, Cambridge, 1993, pp. 5889.

7 DENT, C.M., "Networking the Region? The emergence and impact of Asia-Pacific bilateral free trade agreement projects", Pacific Review, Vol. 16, N. ${ }^{\circ}$ 1, 2003, pp. 1-28; WEI, S. and J. FRANKEL,, "Can Regional Blocs be a Stepping Stone to Global Free Trade? A Political Economy Analysis", International Review of Economics and Finance, Vol. 5, N. . 4, 1996, pp. 339-347.

8 MANSFIELD, E. and MILNER, H., "The New Wave of Regionalism", International Organisation, Vol. 53, 1999, pp. 589-627.

9 For more on economic agreement on growth and liberalisation relationship see MADISON, A., The World Economy: A Millennial Perspective, OECD, Paris, 2001. Despite much agreement the claim that openness leads to growth and development has also been questioned, see RODRIGUEZ. F and RODRIK, D., "Trade Policy and Economic Growth: A Skeptic's Guide to the Cross-national Evidence", in BERNANKE, B. and ROGOFF, K. (eds.), Macroeconomics Annual 2000, MIT Press for NBER, Cambridge MA, 2000.

${ }^{10}$ BALDWIN, R., op. cit. footnote 6, p. 4. 
FTAs as states hope to avoid trade diversion effects on themselves ${ }^{11}$. As liberalization extends via FTAs, states should experience positive welfare gains.

However, models predict marginal welfare gains ${ }^{12}$, and studies estimating outcomes of FTAs between the EU and Asian states also reflect this tendency ${ }^{13}$. As Raymond Ahearn points out in reference to EU and USA FTAs with smaller partners, whilst overall results are meager, "this does not mean individual companies and workers have not benefited or that exports have not risen at faster rates, but that in the aggregate many other factors other than FTAs may be determining how well each side does overall"14. The crux of the matter is that overall welfare gains predicted by the models are asymmetrically distributed with some sectors winning substantial benefits from liberalization and FTAs and others losing out- averaging a lacklustre total.

One of the characteristics of FTAs is that unlike current rounds of negotiations at the WTO, they allow for the exclusion of some sectors from the liberalization package. Sensitive sectors can be left out of negotiations through exclusion lists. ${ }^{15}$ This facilitates the position of the government negotiators who must mediate between the contradictory interests of domestic export-oriented sectors and domestically-focused producers with protectionist leanings. Because this enables policy-makers to circumvent some of the domestic opposition to economic liberalization, John Ravenhill has referred to this as "liberalisation without political pain" (for the government) ${ }^{16}$. Ironically, it is those excluded sectors that would produce the highest welfare gains if they were included within the agreements ${ }^{17}$. For this reason econo-

11 GROSSMAN, G. and HELPMAN, E., "The Politics of FTAs", American Economic Review, Vol. 85, N. ${ }^{\circ}$ 4, 1995, pp. 667-690.

12 HALLAERT, J., "Proliferation of preferential trade agreements: Quantifying its welfare impact and preference erosion", Journal of World Trade, Vol. 42, N. ${ }^{\circ}$ 5, 2008; BALDWIN, R. and VENABLES, J., "Regional Economic Integration" in Handbook of International Economy, Vol. 3, Elsevier, New York, 1995, pp. 1597-1644.

13 IBM BELGIUM Sustainability Impact Assessment. EU-South Korea FTA, Brussels, Commissioned by European Commission, 2008; ECORYS Interim Report. Trade Sustainability Impact Assessment EU-ASEAN FTA. The Netherlands, Commissioned by European Commission, 2009.

${ }^{14}$ HALLAERT, J., "Proliferation of preferential trade agreements: Quantifying its welfare impact and preference erosion", Journal of World Trade, Vol. 42, N. ${ }^{\circ}$ 5, 2008, p. 23.

15 To comply with GATT Article 24 and GATS Article 5, FTAs need to offer substantial liberalisation and not create new barriers for other parties, but it is vague exactly how much of the trade must be liberalised.

16 RAVENHILL, J., "The New Bilateralism in the Asia Pacific", Third World Quarterly, Vol. 24, pp. 299-317.

17 WONNACOTT, P. and LUTZ, M., "Is there a case for Free Trade Areas?", in J. SCHOTT (ed.), Free Trade Areas and US Trade Policy, Institute for International Economics, Washington D.C., 1989, pp. 54-84. 
mists tend to oppose limited scope FTAs, and advocate multilateral liberalisation at the $\mathrm{WTO}^{18}$.

Given the limited economic gains from FTAs, scholars have turned to discern political reasons for governments to engage in complex and lengthy FTA negotiations. Jaghdish Bhagwati, for example, considers the USA a 'selfish hegemon', which while wedded to multilateral outcomes, uses the bilateral approach as a bargaining strategy to divide the non-hegemonic governments and improve the final multilateral outcome in favour of its own preferences ${ }^{19}$. Indeed, since the early 2000 s the USA has pursued a "three-dimensional trade strategy: multilateral, regional and bilateral, so as to exert latent pressure on recalcitrant liberalisers" by concluding FTAs with other states creating "competition in liberalisation" 20 . This deliberate policy plays into assumptions like Baldwin's 'domino theory' which states that, concerned with trade diversion from a new FTA, outsiders will want their own FTA and will be more willing to acquiesce to others' demands, especially when what is at stake is access to some of the world's most important markets (like the USA, EU or China). In a similar vein, since its shift in policy announced in 'Global Europe' in 2006, the EU, too has followed a dual, multilateral and bilateral strategy for liberalization, and in its bilateral FTA has sought to institutionalize future coordination of positions at the WTO with its partners.

Smaller players may not be able to internationalise their preferences in the same way as the USA or EU through FTAs, yet, they too have important political considerations in mind when engaging in FTAs. Apart from not losing out to competitors involved in FTAs, Asian Pacific states, for example, have entered FTAs for various reasons including learning processes, locking in domestic liberalization reforms, sending signals to other potential FTA partners and strengthening their position in other negotiations ${ }^{21}$. Shujiro Urata further argues that the flurry of Asian FTAs was a response to the USA's turn to FTAs with NAFTA (1994) (in a 'domino theory' scenario), and WTO Doha Round difficulties, as well as a way to gain improvements on existing WTO commitments, as these new FTAs typically include facilitation of foreign trade and of investment as well as economic

18 SALLY, R., "China's Trade Policy in Wider Asian Perspective". Paper prepared for the LSE/CCER conference, Beijing, 22/23, 2005, p. 41 (last accessed 23/10/2011). http://www2. lse.ac.uk/internationalRelations/centresandunits/ITPU/docs/sallychinatradepolicy.doc

19 BHAGWATI, J., op. cit., footnote 4.

20 SCHOTT, J., "Free Trade Agreements and US Trade Policy: A Comparative Analysis of US Initiatives in Latin America, the Asia-Pacific Region, and the Middle East and North Africa”, The International Trade Journal, Vol. 20, N. ${ }^{\circ}$ 2, pp. 95-138, p. 98.

${ }^{21}$ AGGARWAL, V.K. and URATA, S., Bilateral Trade Agreements in the Asia Pacific: Origins, Evolution and Implications, Routledge, Basingstoke, 2006. 
and technical cooperation ${ }^{22}$. He further demonstrates FTAs in East Asia have political intentionality; used by some (ASEAN) to promote greater regional integration, by others (China, Japan) as a way of strengthening their ties with ASEAN and other newly industrialized economies as they vie for leadership, and as a way of promoting liberalization and domestic reforms using external commitments as a way of circumventing domestic opposition in the aftermath of the 1997 Asian financial crisis.

Mireya Solis and Saori Katada find evidence of FTAs as tools for diplomatic power, which could explain why FTAs have not developed between the largest economies (EU, China, USA, Japan) but instead between these and smaller players or between smaller economies, as they compete for influence. They explain the proliferation of FTAs in the form of ideational diffusion, whereby states are emulating each others' policies, spurred on by a 'competitive diffusion' in which the policy is implemented in view of what competitors $\mathrm{do}^{23}$. In a sense this is the ideational equivalent to Baldwin's economic 'domino theory'. This paper further refines this idea of 'competitive diffusion' and a 'domino' by borrowing the concept of power balancing from traditional realist conceptions of foreign policy, as explained in subsequent sections. It offers a vision, based on the case of the European Union's FTA strategy in Asia, of FTAs as balance of power tools, deployed not just to avert trade diversion effects ('domino effect') or as emulation ('competitive diffusion') but also to achieve milieu-shaping objectives and to secure future power positions.

\section{The European Union's Trade Policy and FTAs}

Since its establishment in the Treaty of Rome, the EU's trade policy has always purported clear economic objectives, based on liberalisation, which mirrored the internal development of the single market:

By establishing a customs union between themselves the Member States intend to contribute, in conformity with the common interest, to the harmonious development of world trade, the progressive abolition of restrictions on international exchanges and the lowering of customs barriers (Art. 206 Consolidated Treaties) ${ }^{24}$.

${ }^{22}$ URATA, S., "Proliferation of FTAs in East Asia", Paper presented at PECC Trade Forum, Jeju, Korea on 23/05/2005.

23 SOLIS, M. and KATADA, S., "Explaining FTA Proliferation: A Policy Diffusion Framework", in SOLIS, M.; STALLINGS, B. and KATADA, S., Competitive Regionalism. FTA Diffusion in the Pacific Rim, PalgraveMacmillan, Basingstoke, 2009, pp. 1-26.

${ }^{24}$ Consolidated Treaties of the European Union, Official Journal of the European Communities, C83, 30.3.2010, http://eur-lex.europa.eu/en/treaties/index.htm (last accessed 12/01/2012). 
According to the foundational Treaties, this was to be tasked to the European Commission, which from the start was entrusted with the representation of Member States internationally in trade. Scholars in the collusive delegation camp argue that this institutional arrangement afforded the European Commission insulation from domestic settings where protectionist and liberalising interests compete, and allowed it to pursue the liberalisation objective set out in the Treaties. ${ }^{25}$ Others have focused on the influence of economic interests, such as exporters, importers and import-competing interests, and nongovernmental organizations in the formulation of trade poli$\operatorname{cies}^{26}$. Whilst some find interests groups' pressure key in formulating trade policy ${ }^{27}$, others argue that the Member States and European Commission remain autonomous ${ }^{28}$. The complication lies in the fact that given the diverse nature of the EU, and the need to aggregate different sectoral and national interests in determining the policy, and the existence of several veto points (Commission discussion, domestic discussions, bargaining in the Council, European Parliament ratification) creates a complex system where it becomes difficult to discern which interests are being defended, once the EU

25 MEUNIER, S., "What Single Voice? European Institutions and EU-US Trade Negotiations", International Organisation, Vol. 54, N. ${ }^{\circ}$ 1, 2000, pp. 103-135; MEUNIER, S., Trading Voices. The European Union in International Commercial Negotiations, Princeton, Princeton University Press, 2005; WOOLCOCK, S., "European Union Trade Policy: Domestic Institutions and Systemic Factors". In KELLY, D. and GRANT, W. (eds.), The Politics of International Trade in the Twenty-First Century: Actors, Issues and Regional Dynamics, Palgrave Macmillan, Basingstoke, 2005. The liberalizing impulse has not been uniform. The EU maintains a protectionist stance on agricultural issues and also cultural services, and was more protectionist in GATT negotiations in the 1970s and 1980s (see KAHLER, M. "European Protectionism in Theory and Practice", World Politics, Vol. 37, n. ${ }^{\circ}$ 4, 1985, pp. 475-502).

${ }^{26}$ DUR, A. and DE BIEVRE, D., "Inclusion without Influence? NGOs in European Trade Policy", Journal of Public Policy, Vol. 27/ 1, 2007, pp. 79-101; GERLACH, C., "Does Business Really Run EU Trade Policy? Observations about EU Trade Policy Lobbying", Politics, Vol. 26, n. ${ }^{\circ}$ 3, 2006, pp. 176-183.

27 DE BIEVRE, D. and DUR, A., "Constituency Interests and Delegation in European and American Trade Policy", Comparative Political Studies, Vol. 38, n. ${ }^{\circ}$ 10, 2005, pp. 127196; DUR, A., "Bringing Economic Interests Back Into the Study of EU Trade Policy-Making", British Journal of Politics and International Relations, Vol. 10, N. ${ }^{\circ}$ 1, 2008; VAN DEN HOVEN, A., "Interest Group Influence on Trade Policy in a Multilevel Polity: Analysing the EU Position at the Doha WTO Ministerial Conference", EUI Working Paper, RSC N. ${ }^{\circ}$ 2002/67, European University Institute, Florence, 2002.

28 WOLL, C., "Trade Policy Lobbying in the European Union: Who Captures Whom?", In COEN, D. and RICHARDSON, J. (eds.), Lobbying in the European Union: Institutions, Actors and Issues, Oxford University Press, Oxford, 2007; YOUNG, A.R., Extending European Co-operation: The European Union and the 'New' International Trade Agenda, Manchester University Press, Manchester, 2002. 
is negotiating with 'one voice' with third parties. ${ }^{29}$ This complexity is further compounded by the fact that as the EU's first institutionalised foreign policy, trade policy has been linked to the attainment of other foreign policy objectives $^{30}$, making the EU a truly 'conflicted trade power' 31 .

To consolidate certain foreign policy goals (for instance retaining influence in former colonies, stability in its neighbourhood, assisting development, promotion of human rights and a milieu-shaping normative agenda) the EU leveraged its market by offering preferential market access to selected partners, often through FTA arrangements. Some FTAs pursued developmental objectives (Lomé conventions with developing states in Africa, Caribbean and Pacific), others hoped to reinforce political reforms (FTAs with Central and European states in the 1990s), others aimed at forging closer and more stable economic relations with the EU's neighbours (agreements with EFTA, Turkey, Mediterranean Basin states) ${ }^{32}$. Such an array of politically-motivated FTAs perhaps lent credence to economists' complaints about the economic incongruence of FTAs.

In addition to these motivations, in the mid to late 1990s, the EU's first genuinely economically-motivated FTAs appeared. The Global Agreement negotiated with Mexico in 1997, was a response to the creation of NAFTA and the EU's subsequent loss of market share in Mexico ${ }^{33}$. This reflects the logic of the 'domino theory' of FTAs. In a pre-emptive move, the European Commission sought a negotiating mandate and opened FTA negotiations with Mercosur and Chile in 1999. The Association Agreement with Chile (agreed in 2002) and the projected one with Mercosur (under negotiation since 1999) meant to anticipate moves in the Western Hemisphere towards a Free Trade Area of the Americas (which failed), and guarantee EU business access to burgeoning markets in Latin America ${ }^{34}$. These FTAs revealed a policy concerned with competitors and with using FTAs specifically to economically balance against the USA, although the difficulties in gain-

${ }^{29}$ MEUNIER, S., "What Single Voice? European Institutions and EU-US Trade Negotiations", International Organisation, Vol. 54, N. . 1, 2000, pp. 103-135.

${ }^{30}$ BALDWIN, M., "EU Trade Politics- Heaven or Hell?", Journal of European Public Policy, Vol. 13, N. ${ }^{\circ}$ 6, 2006, pp. 926-942.

31 MEUNIER, S. and NICOLAIDIS, K., "The EU as a Conflicted Trade Power", Journal of European Public Policy, Vol. 13, N. ${ }^{\circ}$ 6, 2006, pp. 906-925.

32 LAMY, P., "Stepping Stones or Stumbling Blocs: The EU's Approach Towards the Problem of Multilateralism versus Regionalism in Trade Policy", The World Economy, Vol. 25, N. ${ }^{\circ}$ 10, 2002, pp. 1399-1413, p. 1405.

33 DUR, A., "EU Trade Policy as Protection for Exporters: The Agreements with Mexico and Chile", Journal of Common Market Studies, Vol. 45, N. ${ }^{\circ}$ 4, 2007, pp. 833-855.

${ }^{34}$ GARCIA, M., "Incidents along the Path: Understanding the Rationale behind the EUChile Association Agreement", Journal of Common Market Studies, Vol. 49, N. . 3, 2011, pp. 501-524. 
ing negotiating mandates in the case of Mercosur and Chile ${ }^{35}$ suggest that the 'conflicted trade power' often requires an imminent threat to react with conviction.

Just as these new economically-motivated FTA negotiations were commencing, the EU's FTA policy shifted when the institutional management of FTAs in the European Commission was reformed. In 1999, the Commission reorganised its foreign affairs departments along thematic rather than geographic lines, thus, DG Trade was born. Its first Commissioner, Pascal Lamy (1999-2004), placed a moratorium on starting new FTAs (although ongoing FTA negotiations continued), and instead directed his DG's energies towards attaining extensive multilateral liberalisation at the WTO. The agenda at this time included uploading the so-called Singapore issues into the WTO (services, public procurement, intellectual property (IP) rights and competition policy). Binding agreements on the Singapore issues would have advantages for the EU and other developed economies as their advanced service providers could benefit from access to new markets and potential lucrative public procurement deals elsewhere. This forms part of what Pascal Lamy, himself, described as the EU's 'deep trade' agenda ${ }^{36}$.

Alisdair Young and John Peterson explain the 'deep trade' agenda focused on internationalising the Singapore issues as well as environmental and labour standards, as a response to new dynamics in international trade. Since the late 1980s controversies have revolved around behind-the-border issues (regulations and standards) rather than tariffs and quotas. As the multilateral system encroached on domestic (or EU) regulations through the agreements on Services (GATS) or intellectual property (TRIPS), new players (Parliaments, NGOs, civil society groups) became more active in expressing their voice regarding trade negotiations ${ }^{37}$. Moreover, it also became increasingly apparent that the emerging powers would no longer acquiesce to the EU-US setting the WTO agenda. The Doha Round at the WTO (launched in 2001), was specifically devoted to development to cater for the interests of these new players. Young and Peterson claim that the EU's 'deep trade' agenda was a response to this, and that its developmental stance was brought about through civil society pressure and opin-

35 DG Agriculture, agriculture groups, France, Austria, Ireland were opposed to negotiations with Mercosur given Brazil's competitive agricultural sector, whilst other states, economic sectors and DGs in the European Commission pressed for negotiations. For background on these difficulties see GARCIA, M., The Path to the 2002 Association Agreement between the European Union and Chile. A Case Study of Successful Political Negotiations, Edwin Mellen, New York, 2009, ch. 4.

${ }^{36}$ LAMY, P., op. cit., footnote 32.

37 YOUNG, A.R. and PETERSON, J., "The EU and the New Trade Politics", Journal of European Public Policy, Vol. 13, N. ${ }^{\circ}$ 6, 2006, pp. 795-814. 
ion influencing the trade preferences of social democratic governments at the time (Schroeder's red-green coalition in Germany, Blair's development agenda in the UK), which then shaped the EU's trade policy ${ }^{38}$. In this context, Commissioner Pascal Lamy, himself a socialist, instituted a doctrine of 'harnessing globalisation' consisting of "a broad and encompassing doctrine that subordinated trade policy to a variety of trade and non-trade objectives, such as multilateralism, social justice and sustainable development" ${ }^{39}$, which was defended at the WTO.

From the onset the Doha Round was beset with confrontations and disagreements. By the 2005 Hong Kong Ministerial most of the EU's cherished items on its 'deep trade' agenda had been discarded by emerging powers from the negotiations (rules on competitions, investment policy, labour standards and most of the environmental items). ${ }^{40}$ The EU's preferences in its 'deep trade' agenda live on, however in its unilateral trade policies (e.g. General System of Preferences Plus which grants better access to the EU's market in exchange for compliance on some of its labour and environmental conditions) and also in its bilateral and regional trade agreements.

Just as the EU continues to pursue its thwarted interests outside the WTO, so have other actors. Specifically, the USA, in view of the difficulties in the Doha Round, engaged in an active policy of "competitive liberalisation" engaging in FTAs with individual states (especially in Latin America and Asia), hoping fears of trade diversion would set off a "domino effect' and encourage "recalcitrant liberalisers" to accept the enhanced sectoral liberalisation the US and EU were promoting within the aegis of the WTO ${ }^{41}$ Emulating the USA, and frustrated with the WTO, states in Asia, the world's region where FTAs had traditionally been absent, engaged in a frenzy of FTA negotiations as well ${ }^{42}$, although these FTAs have tended to be 'shallower', i.e. less comprehensive in scope than those negotiated by the USA ${ }^{43}$.

Whilst other actors were pursuing their trade preferences through FTAs (Including establishing regulatory standards or gaining mutual recognitions for these, certain types of IP protection, etc.), the EU continued to hope for a resolution to the Doha Round. When Peter Mandelson took over DG

\footnotetext{
38 Ibid., p. 806.

39 MEUNIER, S., "Managing Globalisation: The EU in International Trade Negotiations", Journal of Common Market Studies, Vol. 45, N. ${ }^{\circ}$ 4, 2007, pp. 905-926, p. 906.

${ }^{40}$ YOUNG, A. and PETERSON, J., op. cit., footnote 37, p. 807.

${ }^{41}$ SCHOTT, J., op. cit., footnote 20, p. 98.

42 URATA, S., op. cit., footnote 22.

${ }^{43}$ SALLY, R., "Looking East: The European Union's New FTA Negotiations in Asia", Jan Tumlir Policy Essays/3/2007, ECIPE, Brussels, 2007.
} 
Trade in late 2004, he and his team, concerned with the rise in USA and other FTAs, and the absence of similar 'deep trade' arrangements for the EU, developed a new EU trade policy, which was encapsulated in the 'Global Europe' Document presented in 2006. 'Global Europe' for the first time established an explicit EU FTA policy and laid out the economic rationale behind FTAs:

The key economic criteria for new FTA partners should be market potential (economic size and growth) and the level of protection against EU export interests (tariffs and non-tariff barriers). We should also take account of our potential partners' negotiations with EU competitors, the likely impact of this on EU markets and economies...

Based on these criteria, ASEAN, Korea and Mercosur (with whom negotiations are ongoing) emerge as priorities. They combine high levels of protection with large market potential and they are active in concluding FTAs with EU competitors ${ }^{44}$.

The choice of immediate FTA partners reveals a balancing imperative, which is reiterated elsewhere in the policy: "[w]here our partners have signed FTAs with other countries that are competitors to the EU, we should seek full parity at least". ${ }^{45}$ India and Russia are mentioned as potential candidates too, if less urgent as they were not in direct negotiations at the time with the USA, and therefore the immediate need to balance against USA competitors was absent. Strengthening strategic links with important emerging markets appears to be a key motivating factor behind EU FTAs with Mercosur, but more especially South East Asia and India. Here the aim is simply to strengthen trade and investment links with markets that will be important in the future ${ }^{46}$, thus attempting to pre-empt any bilateral deals that these future markets may make with EU competitors. Even if the sustainability studies indicate meager overall welfare gains from these FTAs ${ }^{47}$, the fear of being left out of the FTA networks and perhaps having some exporters at a disadvantage to USA or Asian exporters elicits such policy responses. This is in line with the economic rationale of the 'domino theory', the ideational logic of 'competitive diffusion', but also, with the use of

44 EUROPEAN COMMISSION, Global Europe. Competing in the World, Brussels, 2006, p. 11.

45 Ibid., p. 11.

46 WOOLCOCK, S., "European Union Policy Towards Free Trade Agreements", ECIPE Working paper No 3, ECIPE, Brussels, 2007, p. 4.

47 IBM BELGIUM, op. cit., footnote 13; ECORYS, op. cit., footnote 13; DECREUX, Y.; MILNER, C. and PERIDY, N., The Economic Impact of the Free Trade Agreement between the EU and Korea, CEPII/ATLASS, Brussels Study for European Commission, 2010. 
FTAs as tools to maintain an economic balance of power and hedge against another player's preferences becoming the standard.

Trade Commissioner Karel De Gucht's ${ }^{48} 2010$ 'Trade, Jobs and Growth' strategy follows a very similar line to 'Global Europe' with respect to FTAs and the $\mathrm{WTO}^{49}$. The 2010 Strategy continues past trends: it reiterates the aim to complete the Doha Round in $2011^{50}$, prioritises the continuation of competitiveness-driven FTA negotiations ${ }^{51}$, and continues to focus on achieving international liberalisation of public procurement and regulatory regimes ${ }^{52}$. Consistency with the 'deep trade' agenda, and pursuit of EU interests encompassed by it, has been has reiterated by Commissioner De Gucht with respect to negotiations with Asia: "We are not available to do shallow FTAs" ${ }^{\prime 3}$.

\section{An EU Realist FTA Strategy?}

In the post-'Global Europe' era, EU trade policy seeks economic advantages, and to balance against trade diversions and exclusion from preferential arrangements, in a behavior that echoes conceptions of realist foreign policy. Realist and the more nuanced neorealist tradition, view the international arena as an anarchic structure and self-help system besieged by conflictive competition between the actors in the system ${ }^{54}$, sovereign states. Realism's "theory of action is based on a self-interest which is defined in a predominantly materialist" 55 , with actors' behavior is determined by rationalist models of decision-making ${ }^{56}$, where "foreign policy is explained by reference to the goal-seeking behaviour" of self-interested utility-maximis-

48 Trade Commissioner since late 2009.

49 EUROPEAN COMMISSION, Trade, Growth and World Affairs. Trade Policy as a Core Component of the EU's 2020 Strategy, 2010.

50 Ibid., p. 9.

51 Ibid., p. 10.

52 Ibid., p. 6.

53 DE GUCHT, K., "Europe and Singapore: partners in trade, partners for growth", Speech delivered at Lee Kuan Yew School of Public Policy, Singapore, 3 March 2010. http: //europa.eu/rapid/pressReleasesAction.do?reference=SPEECH/10/58 (last accessed 20/11/2011).

54 WALTZ, K., Man, the State and War: A Theoretical Analysis, Columbia University Press, New York, 1959.

55 GUZZINI, S., "The Enduring Dilemmas of Realism in International Relations", European Journal of International Relations, Vol. 10, N. . 4, 2004, pp. 533-568, p. 536.

56 KAHLER, M., "Rationality in International Relations", International Organization, Vol. 52, N. ${ }^{\circ} 4,1998$, pp. 919-941, p. 924. 
ing actors ${ }^{57}$. These approaches tend to define self-interest in terms of strategies seeking to guarantee the security and sovereignty of the state ${ }^{58}$. To ensure security and integrity, states are concerned with their power position vis-à-vis competing states, building power resources (e.g. armies in case of conflict). Hence the importance afforded to concepts like power balancing. In the neorealist framework, states will cooperate only if it furthers their national interests and guarantees absolute or relative gains that are greater to those afforded to the other parties ${ }^{59}$. Although realists perceive states as unitary actors acting within a bounded rationality to first and foremost increase their security, they accept that states also act according to second-order interests which rank below national security and which will be sidestepped if they conflict with core security interests or balance of power logics ${ }^{60}$.

However, interests are not exclusively linked to physical security. Economic and commercial interests are crucial to the functioning of states and just as important in shaping interests and actions, especially in the current globalized world ${ }^{61}$, where states compete for resources to enhance economic growth ${ }^{62}$, market shares and investment. As Robert Gilpin puts it:

in a highly integrated global economy, states continue to use their power and to implement policies to change economic forces favourable to their own national interests and the interests of their citizenry. These national economic interests include receipt of a favourable share of the gains from international economic activities and preservation of national autonomy ${ }^{63}$.

Although the EU is clearly not a state, in trade policy, once the internal decision-making processes of bargaining and interest aggregation have been completed, it acts as though it were a unitary entity in international negotia-

57 FEARON, J. and WENDT, A., "Rationalism versus Constructivism: A Skeptical View", in CARLNAES, W.; RISSE, T. and SIMMONS, B. (eds.), Handbook of International Relations, Sage, London, 2002, pp. 52-72, p. 54.

${ }^{58}$ MEARSHEIMER, J., The Tragedy of Great Power Politics, W.W. Norton, New York, 2001.

59 WALTZ, K., Theory of International Politics, McGraw-Hill, New York, 1979.

${ }^{60}$ MEARSHEIMER, J., op. cit., footnote 58, p. 46.

61 GRIECO, J., "Understanding the problem of international cooperation: the limits of neo-liberal institutionalism and the future of realist theory", in BALDWIN, D. (ed.), Neorealism and Neoliberalism, Columbia University Press, New York, 1993, pp. 301-39; SCHWELLER, R.L., "Realism and the Present Great Power System: Growth and Positional Conflict over Scarce Resources", in KAPSTEIN, E. and MASTANDUNO, M. (eds.), Unipolar Politics: Realism and State Strategies After the Cold War, Columbia University Press, New York, 1999, pp. 28-67.

62 GILPIN, R., The Political Economy of International Relations, Princeton University Press, Princeton, 1987.

63 GILPIN, R., Global Political Economy Princeton University Press, Princeton, 2001, p. 21. 
tions. This justifies an EU level policy analysis and facilitates the application of realist concepts. With the notable exception of Zimmerman's (2007) explanation of the EU's positions on Chinese and Russian WTO accession as based on realist considerations of power rather than domestic mobilization of proliberalisation interests, realism has largely been absent from studies of EU trade policy ${ }^{64}$. However, as the EU's trade policy becomes increasingly concerned with international economic competition and balancing against possible commercial advantages negotiated by other parties, realist (more precisely neorealist) approaches which integrate commercial interests as constituents of national interests can aid in our understanding of events. A realist EU trade policy is, therefore, one where the EU pursues a strategic policy to maximise the benefits to its own economic actors, which includes milieu-shaping rule adoption (exporting its competition policy, IPR rules, labour and environmental standards), gaining allies for multilateral talks, entering a market before competitors, and so on, and not just an increase in short-term absolute trade. Milieu-shaping rule adoption is particularly crucial to the EU's trade policy as it serves a dual purpose of securing material economic advantages, but also serves to further normative aims of the $\mathrm{EU}^{65}$, which highlights what economists have noted "that nothing in their [rationalist] approach prevents taking desires, (or interests or preferences) as being informed by or based on norms". ${ }^{66}$ A turn towards a more explicitly self-interested trade policy is particularly salient since the competitiveness-driven 'Global Europe' agenda of 2006, which responded to a more competitive international environment. In this sense the policy also signified a pragmatic and realist shift.

\section{The European Union's FTA Strategy in East Asia}

\section{EU-Asia Economic Relation Overview}

Over the last decade the economic relationship between Europe and Asia has changed dramatically. Europe-Asia bilateral trade flows have in-

64 ZIMMERMAN, H., "Realist Power Europe: The EU in the Negotiations on China's and Russia's WTO Accession", Journal of Common Market Studies, Vol. 44, N. ${ }^{\circ} 4,2007$, pp. 813-832.

${ }_{65}$ Normative aims of the EU include value promotion (human rights, democracy), but also protecting the EU's social model (which requires others to also adopt higher labour standards). The interplay of material and non-material interests in the EU's grand strategy as an international actor is presented in SMITH, M.E., "A Liberal Grand Strategy in a Realist World? Power, Purpose and the EU's Changing Global Role", Journal of European Public Policy, Vol. 18, N. ${ }^{\circ}$ 2, 2011, pp. 144-163.

${ }^{66}$ FEARON, J. and WENDT, A., op. cit., footnote 57 
creased by more than 50 percent in recent years. Previously both regions directed their largest trade flows to North America, now flows between these two regions are greater than their respective flows to North America. ${ }^{67}$ In 2010 China was the EU's top supplier (18 percent of EU imports) and second market (8.4 percent of EU exports), whilst the EU accounts for about a quarter of China's trade. ASEAN accounted for 5.2 percent of total EU trade, and China, India, Japan and South Korea were amongst the EU's top ten trade partners ${ }^{68}$. Foreign Direct Investment (FDI) flows have followed a similar dynamic, experiencing sharp rises. EU FDI stocks in Asia increased by 74 percent between 2004 and 2009, and account for 15.1 percent of total EU outward FDI. FDI inflows from Asia have risen by 10 percent over the same period and represent 11 percent of total FDI in the EU ${ }^{69}$. As Figures 1 and 2, overleaf, show, even in the depths of the financial and economic crisis besieging Europe since 2008, significant FDI flows have continued.

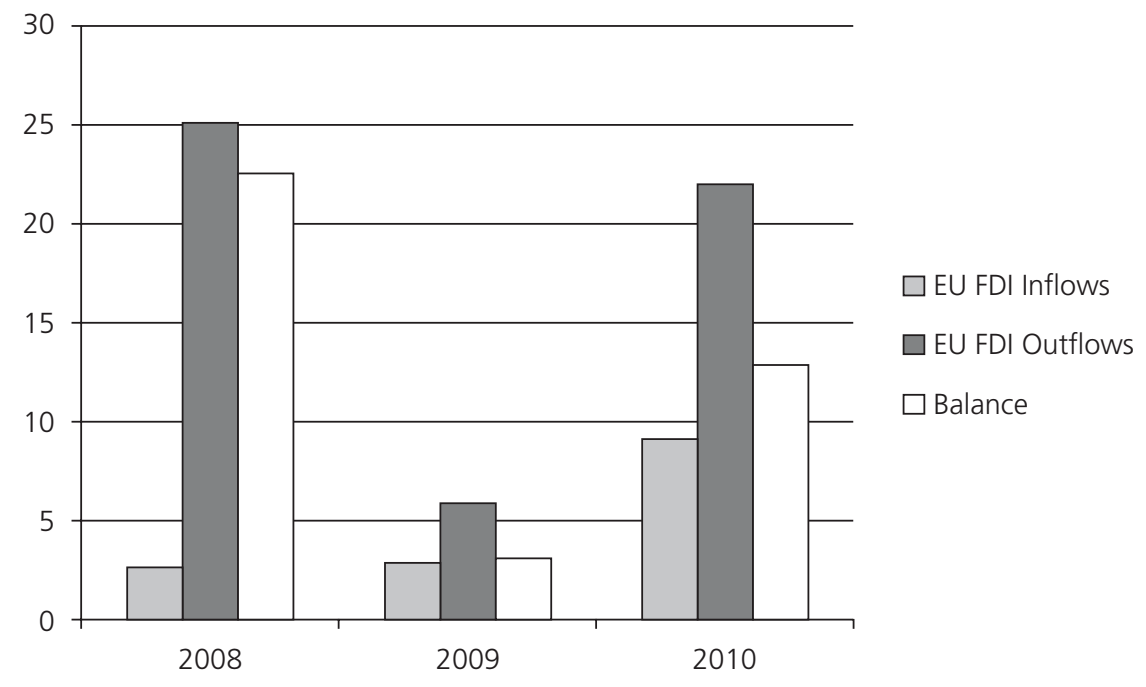

Figure 1

EU-ASEAN FDI Flows (Billion EURO)

${ }^{67}$ GAVIN, B. and SINDZINGRE, A., "EU Trade Relations with Emerging Asia: Identifying the issues", Asia Europe Journal, Vol. 7, N. ${ }^{\circ}$ 9, 2009, pp. 9-22, p. 10.

${ }_{68}$ DG TRADE, European Commission Website: http://ec.europa.eu/trade/creating-opportunities/bilateral-relations/regions/asean/ (last accessed 01/12/2011).

69 Author calculations with data from EUROSTAT EU FDI Extra-EU27 http://epp.eurostat.ec.europa.eu/tgm/refreshTableAction.do?tab=table \&plugin $=0 \&$ pcode=tec00094\&langua ge=en (last accessed 01/12/2011). 


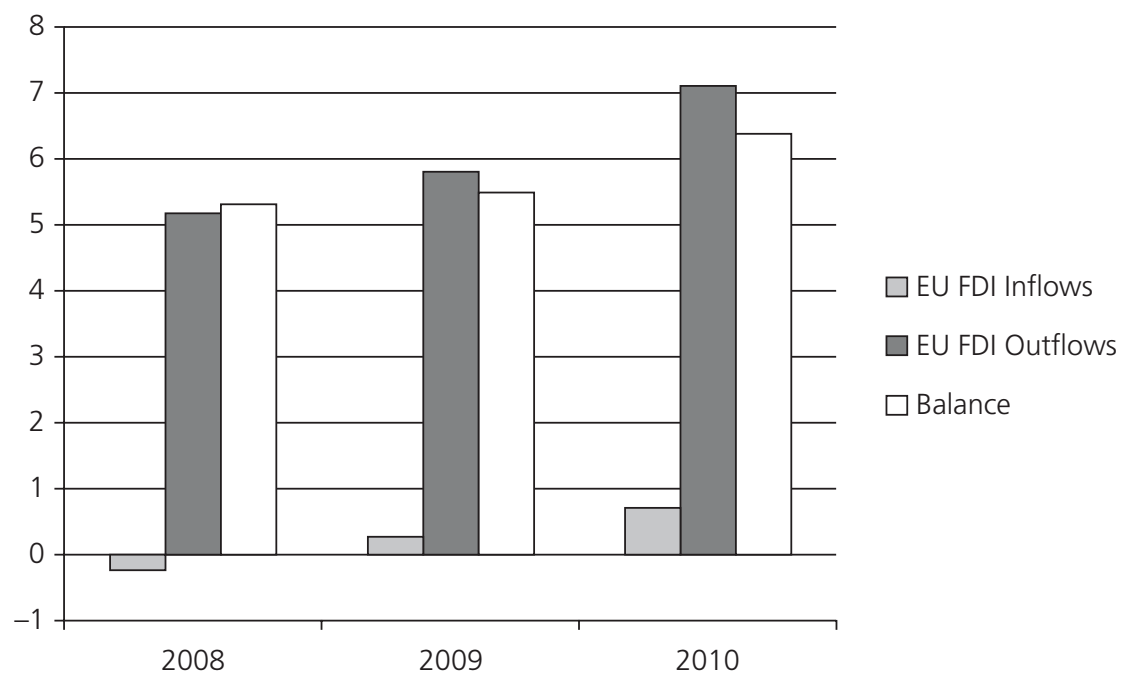

Source: EUROSTAT Comtext.

Figure 2

EU-China FDI Flows (Billion EURO)

Unprecedented economic growth in China, and other emerging states in the region, and these states' greater integration in global markets (not least through the accession of China to the WTO in 2001) has led to this situation. As these states adopted pro-market reforms, they attracted greater FDI, at the same time their export-led growth model (and ability to mass produce consumer goods at competitive rates) has translated in a sharp rise in trade flows. Increased levels of prosperity in emerging states have also signified the appearance of new and populous markets where EU firms want to sell their goods and services (also enhancing trade flows in the other direction). The result is a complex economic relationship, characterized by interdependence between the economies, and not short of idiosyncrasies. Whilst the EU and China, for example, rely on each other, highly mediatic trade conflicts are common in the relationship ${ }^{70}$. Some of these complications arise from the trade imbalances between the EU and Asian states, which are magnified in the case of China. The EU suffers significant trade in goods deficits with Asian states (see Figures 3,4) but displays small surpluses

70 HERON, T., "European Trade Diplomacy and the Politics of Global Development: Reflections on the EU-China 'bra wars' dispute", Government and Opposition, Vol. 42, N. ${ }^{\circ} 2$, 2007, pp. 190-214. 


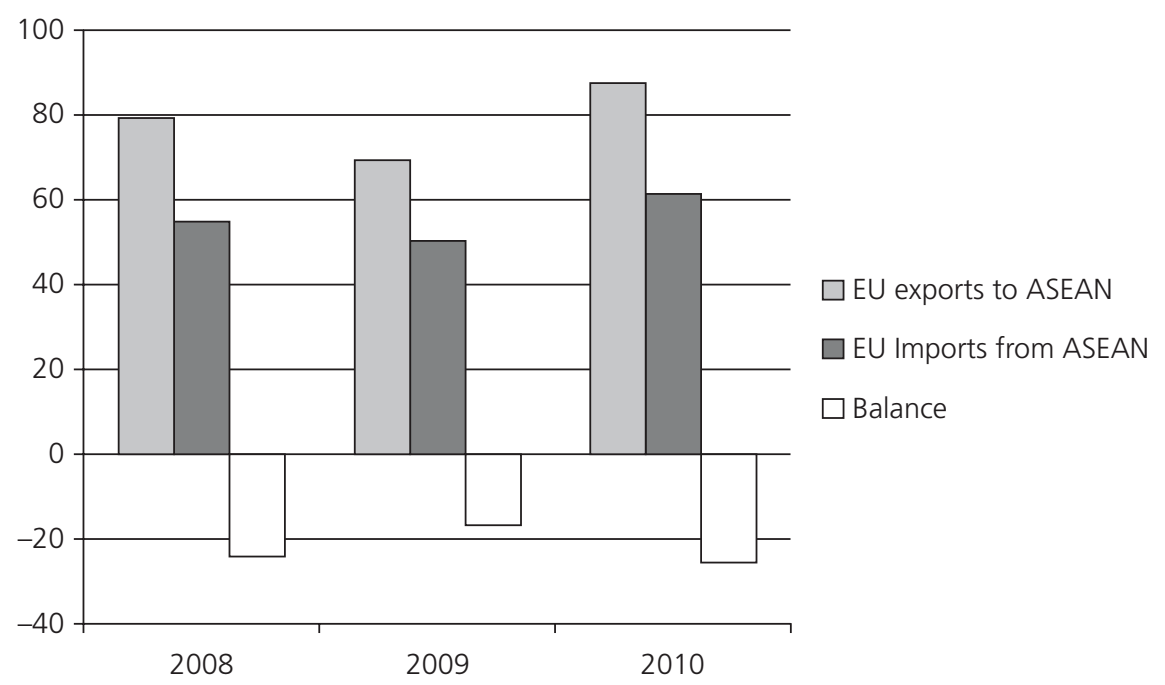

Source: EUROSTAT Comtext.

Figure 3

EU-ASEAN Trade in Goods (Billion EURO)

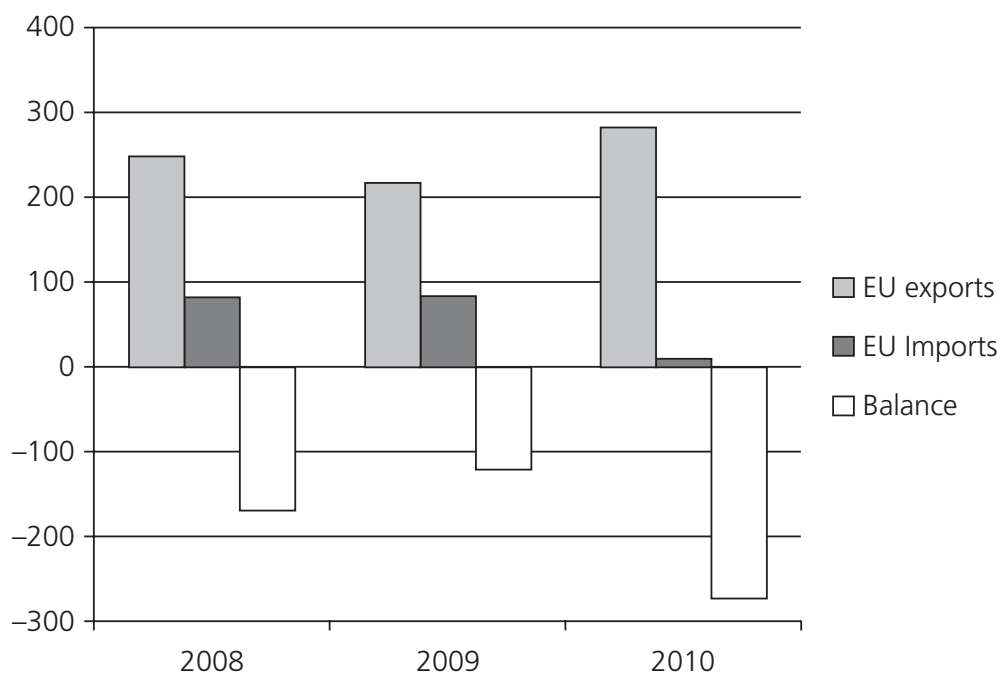

Figure 4

EU-China Trade in Goods (Billion EURO) 


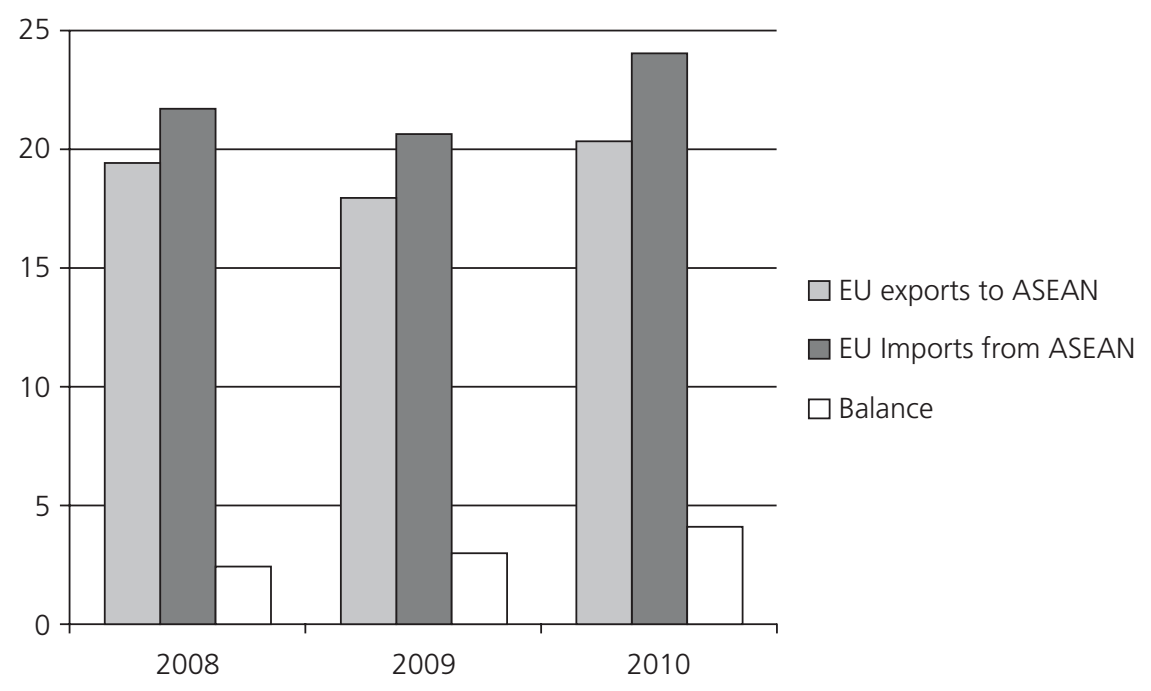

Source: EUROSTAT Comtext.

\section{Figure 5}

EU-ASEAN Trade in Services (Billion EURO)

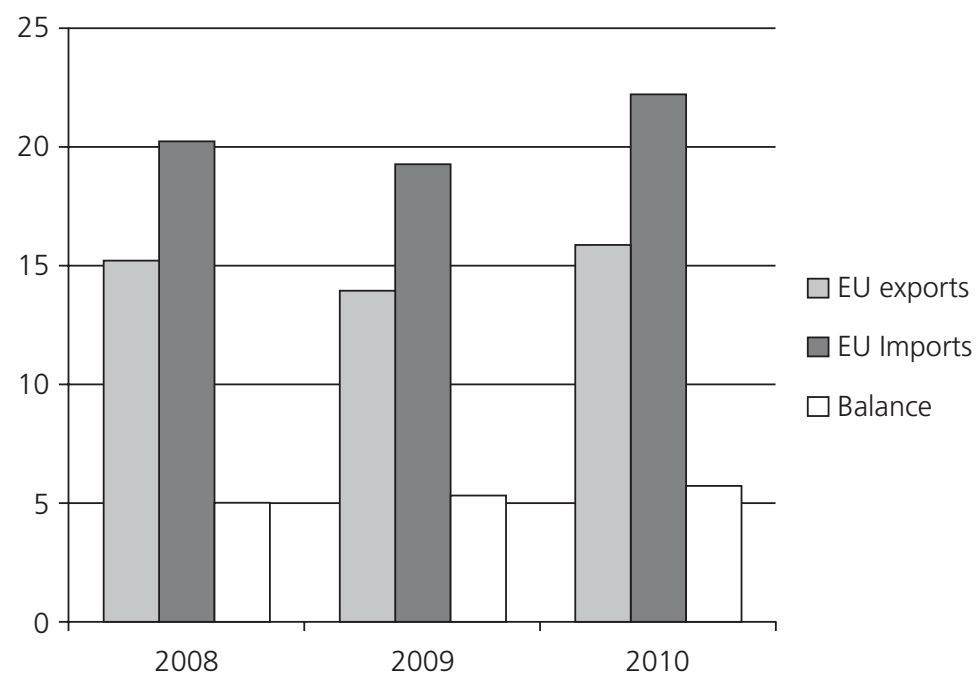

Source: EUROSTAT Comtext.

Figure 6

EU-China Trade in Services (Billion EURO) 
in trade in services (see Figures 5, 6). Asian export-led growth policies, trends in globalization, and the choices of transnational corporations developing international production chains, have created this situation. What is striking is that in contentious issues, such as anti-dumping measures, often EU states, economic sectors, and even particular firms are at odds with each other and EU policies, given their different economic structures and choices ${ }^{71}$.

Trade has been a cornerstone of the EU's strategy for Asia for decades. In 1994, the European Commission launched its 'New Asia Strategy', when Commissioner for the developing world, Manuel Marín, separated the framework policies for Asia and Latin America. The policy stressed concerns with 'losing out' economic opportunities in the region:

The Union stands to lose out on the economic miracle taking place there because of the strong competition: from Japan and the United States, and also increasingly from companies within the region's newly industrialised and capital rich countries such as Korea or Taiwan [...] If European companies are unable to take a full share of the world's main centre of growth in the next decade this will affect their profits and competitiveness, not only in Asian markets, but also world-wide. [...] $]^{72}$

'New Asia Strategy' proposed enhanced discussions, exchanges, linkages between companies and chambers of commerce and discussions on mutual recognition of standards and investment environments as measures to strengthen trade and investment ties and ensure a strong European economic presence in the region. These measures sought to secure EU material interests in the region, and also to establish future milieu-shaping regulatory environments. Acknowledging the diverse levels of development in the region, the strategy also focused on poverty alleviation plans, cooperation in fighting drugs, environmental matters, and also on sponsoring regional integration, (especially through continued support for ASEAN), thus displaying more normative concerns and ambitions as well. ${ }^{73}$ These same topics have remained key aspects of the EU's relations with the region, and reappear in subsequent documents. Concerns with further enhancing economic ties with Asia are also constant throughout time:

71 Countries in the EU that produce shoes demand EU action against Chinese shoe imports, whilst others and consumers demand more imports. Sometimes the competition is between EU firms that have relocated production and other EU firms that have kept production lines in the EU. For more see SHU, M., "Dealing with an emerging economic power: The EU's Trade policy towards China" Paper presented at PSA $60^{\text {th }}$ Annual Conference, Edinburgh, 30/3/2010.

72 EUROPEAN COMMISSION, New Asia Strategy, Brussels, COM(94)314, 1994, p. 18 .

73 Ibid. p. 18. 
[...] we should redouble our efforts to enhance the open multilateral framework for trade and investment, to remove non-tariff barriers to trade and investment, and to enhance the legal, regulatory and technical framework for our economic operators ${ }^{74}$.

Likewise, DG Trade's 'Global Europe' reinforced the trend. It is symptomatic of the importance afforded to Asia by this stage, that 'Global Europe' specifically mentions China in grave terms: "Europe must get China right, as an opportunity, a challenge and prospective partner"75 and the fact that another policy paper dealing exclusively with this relationship accompanied 'Global Europe' 76 . Responding to setbacks in the WTO Doha Round negotiations, where the EU hoped to extend its 'deep trade' agenda preferences, the USA's increased number of FTA negotiations in the Western Hemisphere and Asia, Asian FTAs and Asian economic growth, in its new trade policy, the EU actively sought to extend the EU's economic governance preferences in its relations with Asia. Abandoning Lamy's FTA moratorium and advocating extensive FTAs was a specific tool to address a potential loss of EU competitiveness in emerging markets. 'Global Europe' emphasized this economic imperative in contrast with pre-2000 FTAs which followed developmental and stability goals: "in order for trade policy to help create jobs and drive growth, economic factors must play a primary role in the choice of future FTAs"77.

\section{Competition and Choice of Asian FTA Partners}

A realist emphasis on competitiveness and balancing against the FTAs of the USA is reflected in the choice of FTA partners. ASEAN and South Korea are signaled as immediate priority areas. Korea was in FTA negotiations with the USA, Singapore, Thailand, and Malaysia (ASEAN members) had also negotiated FTAs with the USA. ASEAN states were also involved in FTA negotiations with China, although this FTA which entered into force in January 2010 is less extensive than those negotiated by the USA and EU. Table 1, overleaf, shows the timing of USA and EU agreements and clearly demonstrates this balancing, emulation and 'catch-up' reflex.

74 EUROPEAN COMMISSION, Europe and Asia: A Strategic Framework for Enhanced Partnerships COM (2001) 469, 2001, p. 13.

75 EUROPEAN COMMISSION, op. cit., footnote 44, p. 12. Apart from the trade relationship with the USA this is the only specific relationship that gets its own mention.

76 EUROPEAN COMMISSION, EU-China Closer partners, Growing Responsibilities, $\operatorname{COM}(2006) 632,2006$.

77 EUROPEAN COMMISSION, op. cit., footnote 44, p. 11. 
Table 1

Comparative Timeline of EU, USA, Chinese, FTAs in Asia

\begin{tabular}{|c|c|c|c|c|c|c|}
\hline & $\begin{array}{c}\text { CHINA } \\
\text { start }\end{array}$ & $\begin{array}{c}\text { CHINA } \\
\text { end }\end{array}$ & $\begin{array}{l}\text { USA } \\
\text { start }\end{array}$ & $\begin{array}{l}\text { USA } \\
\text { end }\end{array}$ & $\begin{array}{l}\text { EU } \\
\text { start }\end{array}$ & $\begin{array}{l}\text { EU } \\
\text { end }\end{array}$ \\
\hline ASEAN & 2001 & $\begin{array}{c}2007 \\
\left(2010^{*}\right)\end{array}$ & & & 2007 & $\begin{array}{l}\text { Suspended } \\
2010\end{array}$ \\
\hline Hong Kong & & 2003 & & & & \\
\hline Macao & & 2003 & & & & \\
\hline Thailand & & 2003 & $\begin{array}{r}2004 \text { (suspen } \\
\text { regime }\end{array}$ & $\begin{array}{l}\text { ed } 2006 \text { after } \\
\text { hange) }\end{array}$ & & \\
\hline Singapore & & 2008 & TPP^ 2008 & 2003 (2004) & 2010 & \\
\hline $\begin{array}{l}\text { South } \\
\text { Korea }\end{array}$ & & & 2006 & $\begin{array}{c}2007 \\
\text { (end 2011) }\end{array}$ & 2007 & $\begin{array}{c}2009 \\
(\operatorname{mid} 2011)\end{array}$ \\
\hline Malaysia & (ASEAN) & & $\begin{array}{l}2006 \text { (prior tr } \\
\text { framework aq }\end{array}$ & $\begin{array}{l}\text { le investment } \\
\text { eement 2004) }\end{array}$ & 2010 & \\
\hline Vietnam & $(\mathrm{ASEAN})$ & & TPP 2008 & & 2010 & \\
\hline Myanmar & (ASEAN) & & & & & \\
\hline \multicolumn{7}{|l|}{ Japan } \\
\hline Pakistan & & 2006 & & & & \\
\hline Brunei & & & TPP 2008 & & & \\
\hline India & $\begin{array}{r}2008 \text { Fea } \\
\text { study- highl }\end{array}$ & $\begin{array}{l}\text { sibility } \\
\text { y unlikely }\end{array}$ & Commerc & I dialogue & 2007 & \\
\hline
\end{tabular}

ASEAN: Brunei Darussalam, Cambodia, Indonesia, Lao PDR, Malaysia, Myanmar, Philippines, Singapore, Thailand, Viet Nam.

Dates in brackets represent implementation dates when these differ from conclusion of negotiations.

* 2010 for Brunei Darussalam, Malaysia, Singapore, Philippines, Thailand, Indonesia, 2015 for others.

$\wedge$ TPP stands for Transpacific Partnership.

Sources: European Commission DG Trade website, US Trade Representative website, ASEANWEB $(2011)^{78}$.

78 ASEANWEB http://www.asean.org/20164.htm; European Commission Trade Website http://ec.europa.eu/trade/creating-opportunities/bilateral-relations/free-trade-agreements/; India Business http://business.gov.in/trade/trade_agreements.php; MOFCOM Chinese Ministry of Foreign Trade http://fta.mofcom.gov.cn/english/fta_qianshu.shtml; USTR United States Office of the Trade Representative http://www.ustr.gov/trade-agreements/free-trade-agreements (all last accessed 12/12/2011). 
The realist imperative of balancing against competitors, maintaining economic footholds in the region and impacting economic governance through the standards and norms negotiated in FTAs, is evident in the choice of partners, and also in the underlying desire to pursue FTAs that were estimated to afford very meager overall welfare returns to the EU. South Korea is the EU's $8^{\text {th }}$ largest trading partner (2.3\% of EU trade) and the EU is Korea's second export destination, yet GCE models predicted welfare effects on GDP of this agreement at 0.08 percent for the EU and between 0.4 and 2 percent for South Korea, as a result of potential higher FDI. ${ }^{79}$ Benefits of FTAs are distributed unevenly across economies and sectors, accounting for overall limited returns, even when rises in Korean exports to the EU of 34 percent and of 82 percent for EU exports were expected. ${ }^{80}$ In a comprehensive EU-ASEAN FTA scenario welfare gains as percentage of GDP were estimated at $0.23 \%$ for the EU and 3.66 to $15.27 \%$ for different ASEAN states, and in the case of a restrictive FTA at merely $0.02 \%$ and $0.08-1.92 \%$ respectively, ${ }^{81}$ with ASEAN states gaining additional market access to the EU and European transnational corporations strengthening their impact in the ASEAN region. In essence, a longer-term balancing and competitiveness strategy, (securing favourable intellectual property regulations, public procurement treatment, and access to future business opportunities) is at play in these FTA negotiations, rather than short-term overall economic gains.

Further evidence of this can be found in the fact that a FTA with South Korea was prioritised, but not one with Japan, even though Japan is the EU's $6^{\text {th }}$ trade partner and accounts for 3.2 percent of EU total trade $(0.9 \text { percent more than South Korea })^{82}$. The reason for this is the EU chose to focus on the faster growing markets in the region (ASEAN and South Korea $)^{83}$, but also the fact that Japan was not in negotiations with the USA. Fearing that its manufacturers would be disadvantaged once the EU reduced tariffs on Korean manufactures, Japan asked the EU to initiate FTA negotiations in 2010, in line with 'domino theory' predictions. ${ }^{84}$ Even then, the EU remained lukewarm, partly to facilitate the passage of the Korea FTA in the European Parliament without fears of extending those advantages to Japan.

${ }^{79}$ IBM BELGIUM, op. cit., footnote 13, p. 13.

${ }^{80}$ DECREUX et al., op. cit., footnote 47, p. 6.

${ }^{81}$ ECORYS, op. cit., footnote 13, p. 18.

82 EUROPEAN COMMISSION, Relations with Japan Website http://ec.europa.eu/trade/ creating-opportunities/bilateral-relations/countries/japan/ (last accessed 25/12/2012).

83 JAPAN TODAY, 'For EU, Japan not as attractive as other Asian economies' 01/05/2010.

${ }^{84}$ FALETTI, S., "FTA Deal with Seoul to boost EU's trade offensive in Asia", Europolitics, $13 / 10 / 2010$. 
However, intensifying ongoing dialogues on regulatory reform and nontariff barriers, in May 2010, Japan and the EU did establish a high level group to discuss upgrading their economic relationship and study a potential FTA. Although negotiations have not begun, the results of the EU's public consultation in November 2010 were favourable to a FTA, as is Japanese business $^{85}$, and future negotiations are likely. Japan is negotiating with ASEAN, as is South Korea, in what in effect would "network" the entire East Asia region through ASEAN plus Three FTAs ${ }^{86}$, and is also considering entering the negotiations of a Transpacific Partnership with the USA, Australia, New Zealand, Brunei, Chile, Peru, Singapore, Malaysia and Vietnam. Within this context, Japan becomes a more attractive, and pressing, FTA prospect within the EU's competitiveness and balancing agenda.

\section{Negotiating FTAs with Asian states}

When the EU did enter negotiations with Asian states following 'Global Europe', it did so with ASEAN, South Korea and India in 2007. All sets of negotiations progressed more slowly than had been envisaged. In the case of ASEAN, differences in levels of development and preferences amongst ASEAN members and the EU's requirements that its FTAs encompass more than trade, but also investment, procurement, intellectual property rights, and a host of political clauses, complicated the negotiations. The Philippines, for example, signaled from the start that the political cooperation agreement would be problematic as it requires signatories to become members of the International Criminal Court ${ }^{87}$.

Shifting from its previous trade strategy prioritizing multilateral and interregional negotiations (with ASEAN, Mercosur, Central America), which had even been characterized by some as "a doctrine of global policy-based on interregionalism", 88 Trade Commissioner De Gucht (since 2009) on a trip to South East Asia in March 2010 announced the launch of negotiations for a FTA with Singapore and with Vietnam, and in November that year he launched negotiations with Malaysia. The move to bilateral deals seems to

85 EUROPEAN COMMISSION, Public Consultation, 2012 http://trade.ec.europa.eu/ consultations/?consul_id=148 (last accessed 15/02/2012).

86 DENT, C., "Networking the Region? The emergence and impact of Asia-Pacific bilateral free trade agreement projects", Pacific Review, Vol. 16, N. ${ }^{\circ} 1$, 2003, pp. 1-28.

87 Bilaterals Webiste, www.bilaterals.org (last accessed 10/12/2012).

88 SODERBAUM, F., STRALGREN, P. and VAN LAGENHOVE, L., "The EU as a Global Actor and the Dynamics of Interregionalism: A Comparative Analysis", European Integration, Vol. 27, N. 3 , 2005, pp. 365-380, p. 371. 
reflect a more pragmatic approach to FTAs, as a bilateral deal will be easier to negotiate than a FTA with another regional grouping that often lacks the level of institutional unity in the negotiations that the European Commission has developed ${ }^{89}$. The bilateral approach also enables the EU to keep up mainly with USA FTAs, which included FTAs with Singapore and Malaysia and negotiations with Vietnam within the Transpacific Partnership, as well as keeping up with China's and Japan's FTAs in the region. In the particular case of the EU-ASEAN FTA, the bilateral approach would also allow European governments to avoid taking on any commitments that support the regime in Myanmar and also to deal with the economic heterogeneity among ASEAN members. ${ }^{90}$ Notwithstanding this, the EU remains intent on an eventual bloc-to-bloc FTA with ASEAN as highlighted by De Gucht himself:

The launch of FTA negotiations with Singapore, for us, marks the beginning of a deeper engagement with Asia, and in particular in our relations with the ASEAN region.

Although Singapore is the 'first one in', our door remains open for other ASEAN countries interested in negotiating a comprehensive free trade agreement with us. We are not available to do shallow FTAs, but we will be mindful of differences in levels of development ${ }^{91}$.

Due to the nature of ongoing negotiations, little data is available about the negotiations with Singapore, Vietnam, Malaysia, and India. Given Singapore's open economy, its competitive service sector, negotiations should be easier than with the other partners as some of the EU's liberalization requirements in services will not be challenging for the city-state. On the other hand, EU requirements for opening public procurement markets are proving difficult to reconcile with the developmental economic policies of partners like Malaysia, India and Vietnam, whose governments use public contracts to direct FDI to particular regions. The EU Head of Delegation in Malaysia claimed progress had been made in the negotiations, but conceded in September 2011 that negotiations would be complicated ${ }^{92}$.

Negotiations with India, which were initially scheduled to conclude in 2009, continue in 2012. EU demands for opening public procurement ten-

89 ROBLES, A., "An EU-ASEAN FTA: The EU's Failures as an International Actor", European Foreign Affairs Review, Vol. 13, N. . 4, 2008, pp. 541-560, p. 337.

90 Bilaterals Website, op. cit., footnote 87.

91 DE GUCHT, K., op. cit., footnote 53.

92 MALAYSIA DIGEST, "Fifth Round of EU-Malaysia Negotiations" 30/09/2011 http:// malaysiandigest.com/business/32357-fifth-round-fta-negotiations-between-malaysia-eu-inmid-oct.html (last accessed 30/09/2011). 
ders have been heavily resisted by Indian negotiators and, as a face-saving measure for both parties, India has agreed to open the federal level public procurement market. However, most public contracts occur at the state level, and EU firms would be excluded from these. EU intellectual property provisions (and their effects on Indian generic medicine production), different preferences in the liberalization of services (with the EU wanting banking liberalization, and India liberalization in visas for short-term service provision in IT) have been significant stumbling blocs as well ${ }^{93}$. EU negotiators hope to finalise an agreement in 2012, but the final outcome remains uncertain. Negotiations with India represent an interesting case: given India's economic growth and future significance, it was signalled as a secondorder FTA priority in 'Global Europe' but negotiations were launched at the same time as with first-order priority states. Apart from securing its future position in India, negotiations aimed to ensure the EU would not lose out to a potential FTA with the USA, which although as yet uninitiated, has been subject of speculation for years. Influenced by its own desire to avoid losing out to advantages negotiated by its main competitors, the USA is increasingly interested in negotiating a FTA with India given EU negotiations ${ }^{94}$. Its wishes to strengthen the USA-India strategic partnership as part of its containment of China and its international strategy against terrorism, further account for talks about a possible USA-India FTA ${ }^{95}$.

Balancing against potential advantages negotiated by the USA, was a key motivation behind EU negotiations with South Korea. Although the USA had commenced negotiations earlier, in the end the EU finalised its FTA with Korea sooner and its ratification took place six months ahead of that of the USA-Korea FTA. Despite the Korean government's keen interest in FTAs, and having already agreed to liberalise services and public procurement with the USA, negotiations were more complex than EU negotiators had expected. Whilst the EU assumed Korea would grant it USA parity, "Korea did not see any reason why [this] should be the case given the very different stakes involved in the [Korea-EU] and [Korea-USA] negotiations" due to the different trade and investment patterns between the EU and Korea and the USA and Korea ${ }^{96}$. Disagreements over the extent of liberalisa-

${ }^{93}$ KHORANA, S. and PERDIKIS, N., "EU and India Free Trade Agreement: Deal or No Deal?", South Asia Economic Journal, Vol. 11, N. ${ }^{\circ} 2$, 2010, pp. 181-206.

94 PREEG, E.H., "The Growing US Interest in a Free Trade Agreement with India”, Economic Report, MAPI (Manufacturers Alliance), Virginia, 2011.

95 CURTIS, L. and CHENG, D., "The China Challenge: A Strategic Vision for US-India Relations", Backgrounder, The Heritage Foundation, MA., 2011.

96 NICOLAS, F., "Negotiating a Korea-EU free trade agreement: easier said than done", Asia Europe Journal, Vol. 7, 2009, pp. 23-42, p. 42. 
tion of the EU market to Korean car exports were protracted, and even parts of the political cooperation framework agreement caused controversy. In the end, in the political agreement the EU did persuade Korea to acquiesce to some core labour standards set out by the International Labour Organisation (ILO) ${ }^{97}$. What this shows is that even with the most willing partners, negotiations are likely to be complex, as each party aims to gain its preferences, and as FTAs are used a way of achieving partial liberalization, whilst protecting sensitive sectors. Given the EU's complex and comprehensive set of preferences as exemplified in its 'deep trade' agenda, future negotiations are likely to be lengthy and complicated, especially given the resistance many emerging powers have already expressed to the EU's milieu-shaping 'deep trade' policy aims within the context of the WTO Doha Round.

\section{Concluding Remarks}

The increasing economic and political significance of Asia, and the state of complex economic interdependence that has arisen from liberalization reforms throughout the region, and the transnationalisation of production lines, has understandably turned this part of the world into a key priority area for the European Union, especially for its external economic policy. From that perspective institutionalizing ties, engaging in facilitation of behind-the-borders trade and investment, setting of mutual standards for safety, labour and environmental conditions, is indeed of the upmost necessity for the EU. Mutual standards are promoted as protection against social dumping and from the economic perspective of creating a more level economic playing field with minimal guaranteed regulations, are an economic imperative, rather than necessarily as a normative commitment to the European welfare state. Nevertheless, externalizing its regulatory model (or agreeing to a mutual international one) is especially significant as the EU's international strategy aims to also protect its own internal regulatory project (amongst it the vestiges of the European social model) ${ }^{98}$.

In its relationship with China, economically its most significant and complex relationship in the region, the EU is proceeding cautiously through the development of twenty-six specialist dialogues on various aspects of the economic and political relationship. This takes place within the, as yet un-

97 WOOLCOCK, S., "Assessment of the EU-Republic of Korea FTA", Presentation for the European Parliament Hearing 23/06/2010 available at http://www.europarl.europa.eu/eplive/en/committees/video?event=20100623-0900-COMMITTEE-INTA\&vodtype $=$ Vod $($ last accessed 15/01/2012).

98 SMITH, M.E., op. cit., footnote 65. 
derdeveloped, Strategic Partnership ${ }^{99}$, rather than through the more holistic and binding approach encapsulated in its FTAs and accompanying political cooperation framework agreements. Instead the EU has focused its negotiating energies on other key players in the region, engaging in FTA that are expected to result in only marginal overall economic welfare increases (especially for the EU).

The narrative of the EU's FTA policy, with its sharp shift in 'Global Europe' instigated by the failure to internationalise the EU's economic and milieu-shaping interests embedded in its 'deep trade' agenda through the WTO Doha Round, reveals a realist trade policy concerned with balancing against competitors, especially the USA. This is apparent in the 'competitiveness' discourse, with which the European Commission defends and promotes its more activist policy, its 'competitiveness-driven FTAs', and also in its choice of FTA partners in Asia. The EU's policy of 'catchingup' with USA FTAs, and pre-empting potential future ones, is consistent with economic 'domino theories' of FTAs and ideational 'competitive diffusion' approaches, but also with a realist policy of active economic power balancing, and more importantly, securing future influence by shaping economic governance through FTAs. To the extent that the EU manages to negotiate comprehensive 'deep trade' FTAs with Asian states (as in the case of South Korea), FTAs will be supporting the EU's trade interests and ensuring it remains a key player in the region, and globally. The adoption of its preferred regulations by others (or the setting of joint standards internationally) will afford it and its businesses future advantages, not least from not having their standards undercut by others and preventing others' standards from becoming the norm and then having to undertake the cost of changing their own standards for export markets. Apart from the pragmatic and technocratic advantages of this, influencing governance and developing stable relationships (through the accompanying political framework agreements) could become even more crucial in easing tensions in an uncertain future, where Mark De Vos foresees greater tensions over competing models of trade, monetary issues and capitalism ${ }^{100}$.

However, extensive agreements may not always be plausible. In the EU-India negotiations, the EU has not achieved the desired degree of public procurement liberalization for example. Given that EU FTA preferences

99 See HOLSLAG, J., "The Elusive Axis: Assessing the EU-China Strategic Partnership", Journal of Common Market Studies, Vol. 49, N. ${ }^{\circ} 2$, 2011, pp. 293-313; SMITH, M. and XIE, H., "The European Union and China: The Logics of Strategic Partnership", Journal of Contemporary European Research, Vol. 6, N. ${ }^{\circ}$ 4, 2010.

100 DE VOS, M., After the Meltdown: The Future of Capitalism and Globalisation in the Age of Dual Crises, Shoehorn, London, 2010 
represent only certain interests and not others, this may not necessarily be a negative outcome. However, from the standpoint of influencing future governance, if the EU's preferences are diluted through individual FTA negotiation processes, then FTAs will fail to secure future positions, and will, at the most, represent lengthy enterprises to retain the status quo. In this backdrop, fears of future competition have become a crucial motivation behind FTA propagation, not least the EU's balancing and realist FTA policy in Asia. Overall, the result of seeking influence through FTAs has meant that the large players have signed FTAs with smaller states to hedge against negative trends preventing the predominance of any hegemonic FTA project, thus far ${ }^{101}$.

101 MOCHIZUKI, M., "Political-Security Competition and the FTA Movement: Motivations and Consequences", in SOLIS, M.; STALLINGS, B. and KATADA, S., Competitive Regionalism. FTA Diffusion in the Pacific Rim, PalgraveMacmillan, Basingstoke, 2009, pp. 54-73. 